\title{
HUBUNGAN ASUPAN ZAT GIZI MAKRO DAN STATUS GIZI IBU MENYUSUI DENGAN KANDUNGAN ZAT GIZI MAKRO PADA AIR SUSU IBU (ASI) DI KELURAHAN BANDARHARJO SEMARANG
}

\author{
Ruliansyah Kusuma Wardana ${ }^{1}$, Nurmasari Widyastuti ${ }^{1}$, Adriyan Pramono $^{1}$ \\ ${ }^{1}$ Departemen Ilmu Gizi, Fakultas Kedokteran, Universitas Diponegoro \\ Jln. Prof. H. Soedarto, SH., Semarang, Telp (024) 76402881, Email : gizifk@undip.ac.id
}

\begin{abstract}
Background : The malnutrition can be the one reason of the Increasing of Infant Mortality (IMR). Malnutrition problem known > 2 cases happened in Bandaharjo Kelurahan Semarang City. The decreasing of malnutrition problems can be done by pay attention to food intake for breastfeeding mother, the amount of the food intake also should be based on nutritional status that will give effect to the quality of breast milk (ASI). If the food intake in breastfeeding mother is not sufficient for the energy, carbohydrates, fats, and proteins, it will cause the risk of decreased quality of macro nutrients in breast milk that can lead to inhibition of cognitive growth in infants.

Method: The study was conducted in Bandaharjo Kelurahan, Semarang by Cross-Sectional method with 42 breastfeeding mothers and 1-12 months infants as the subject. The selection of subjects is purposively and appropriate with the inclusion criteria. The breastfeed data of $100 \mathrm{ml}$ were tested in pathology laboratory of Kariadi Hospital. The intake of energy, carbohydrates, fats, and proteins is obtained from 24-hour recall interview. The nutritional status data obtained through measurement of height and weight then calculate the IMT. The data analysis used is statistical program, while normality test used is Shapiro-Wilk test followed by Pearson correlation test.

Result : The age range of subjects was 17-40 years. Most of the subjects had over nutritional status (64.4\%). As much as $64 \%$ fats intake is in over category, energy intake in less category (50\%), 90\% carbohydrate intake in less category and protein intake $(45 \%)$ in less category. The nutritional status was not related to breastfeed energy content $(p=0,540)$ breastfeed carbohydrate content $(p=0,742)$, breastfeed fats $(p=0,472)$, breastfeed protein $(p=0,296)$, yet there was a relation of mother's energy intake with the breastfeed energy $(p=0,021)$ of breastfeed carbohydrate $(p=0.040)$, breastfeed fats $(p=0.043)$, and breastfeed protein $(p=0.031)$, the carbohydrate intake with breastfeed carbohydrate $(p$ $=0,000)$, the fats intake with breastfeed fat $(p=0,000)$, protein intake with breastfeed protein $(p=0.000)$.

Conclusion: There is a relation between the intakes of macro nutrition of breastfeeding mother with the breastfeed macro nutrition content. There is no relation between mother's nutrition statuses with the breastfeed macro nutrition content.
\end{abstract}

Keywords: macro nutrition intake, nutritional status, breastfeed macro nutrient content, breastfeeding mothers breastfeeding mothers

\begin{abstract}
ABSTRAK
Latar Belakang : Peningkatan Angka kematian Bayi (AKB) salah satunya dapat disebabkan karena gizi buruk. Gizi buruk di Kota Semarang pada Kelurahan Bandaharjo ada >2 kasus. Masalah gizi buruk dapat dilakukan dengan memperhatikan asupan zat gizi makro, banyak sedikitnya asupan ibu berdasarkan status gizi memberikan pengaruh terhadap kualitas air susu ibu (ASI). Jika asupan makanan pada ibu menyusui tidak tercukupi energi, karbohidrat, lemak, dan protein akan beresiko mengalami penurunan kualitas.

Metode : Penelitian dilakukan Kelurahan Bandaharjo, Semarang dengan metode Cross-Sectional, subjek 42 orang ibu menyusui dengan bayi usia 1-12 bulan. Pemilihan subjek secara purposive dan memenuhi kriteria inklusi. Data kandungan ASI sebanyak 100ml yang diujikan pada laboratorium patologi RSUP Kariadi. Asupan energi, karbohidrat, lemak, dan protein dengan recall 24 jam. Data status gizi didapat dengan pengukuran tinggi dan berat badan kemudian dihitung IMTnya. Analisis data menggunakan program statistik, uji normalitas menggunakan uji Shapiro-Wilk dilanjutkan uji korelasi Pearson.

Hasil : Rentang usia subjek 17-40 tahun. Sebagian besar subjek memiliki status gizi lebih (64,4\%). Sebanyak 64\% asupan lemak kategori lebih, asupan energi dengan kategori kurang (50\%), asupan karbohidrat dengan kategori kurang 90\% dan asupan protein dengan kategori kurang (45\%). Status Gizi tidak berhubungan dengan kandungan energi ASI $(p=0,540)$ karbohidrat ASI $(p=0,742)$, lemak ASI $(p=0,472)$, protein ASI $(p=0,296)$, dan terdapat hubungan asupan energy ibu dengan energi ASI ( $p=0,021)$ karbohidrat ASI ( $p=0,040)$, lemak $A S I(p=0,043)$, dan protein $A S I(p=0,031)$, asupan karbohidrat dengan karbohidrat ASI $(p=0,000)$, asupan lemak dengan lemak $A S I(p=0,000)$, asupan protein dengan protein $\mathrm{ASI}(\mathrm{p}=0,000)$.
\end{abstract}

Simpulan : Terdapat hubungan pada asupan zat gizi makro ibu menyusui dengan kandungan zat gizi makro pada ASI. Tidak ada hubungan status gizi ibu dengan kandungan zat gizi makro pada ASI.

Kata Kunci : asupan zat gizi makro, status gizi, kandungan zat gizi makro ASI, ibu menyusui 


\section{PENDAHULUAN}

Salah satu kandungan zat gizi dalam ASI yang memberikan pengaruh pada pertumbuhan, perkembangan dan kesehatan bayi adalah kandungan zat gizi makro ${ }^{1}$. Zat gizi makro pada ASI berupa karbohidrat, lemak dan protein. Kandungan karbohidrat dalam ASI berbentuk laktosa. Laktosa didalam usus halus dipecah menjadi glukosa dan galaktosa oleh enzim laktase. Enzim laktase yang diproduksi pada usus halus bayi terkadang tidak mencukupi, namun dengan diberikannya ASI pada bayi maka kebutuhan enzim laktase dapat tercukupi dengan terpenuhinya kebutuhan sebesar $7,2 \mathrm{~g}^{1,2}$. Kandungan protein pada ASI diharuskan sebesar $0,9 \mathrm{~g}$ mengandung asam amino yang memiliki peran penting untuk pertumbuhan bayi. Lemak tersebut digunakan untuk mencukupi kebutuhan sebagian besar energi bayi. Kadar lemak dalam ASI adalah 3,2$3,7 \mathrm{~g} / \mathrm{dL}$ dan perkiraan energi yang dihasilkan berkisar $65-70 \mathrm{kcal} / \mathrm{dL}$ sehingga terdapat korelasi yang cukup tinggi antara energi yang diperlukan oleh bayi dengan lemak yang dihasilkan pada $\mathrm{ASI}^{3}$.

Kandungan ASI dapat dipengaruhi oleh asupan makanan dan status gizi. Asupan makanan dengan kandungan zat gizi makro berubah menjadi cairan ASI ketika makanan tersebut dicerna dalam tubuh lalu dibawa oleh sel darah menuju keseluruh tubuh dan salah satu tempat pemberhentian zat gizi tersebut adalah pada kantung $\mathrm{ASI}^{4}$. Asupan zat gizi makro makanan selama menyusui perlu ditingkatkan, karena selama menyusui ibu membutuhkan energi ekstra untuk pemulihan setelah persalinan dan proses metabolisme pembentukan $\mathrm{ASI}^{3,5}$. Pada bulan pertama persalinan, produksi ASI umumnya sangat banyak untuk bayi sehingga ibu akan lebih cepat haus serta lapar. Agar jumlah kalori yang keluar tersebut seimbang maka diperlukan asupan makanan dengan gizi seimbang untuk pembentukan ASI. Rata-rata volume ASI pada wanita dengan status gizi baik berkisar 700-800 ml/hari ${ }^{5}$. Menurut Marmi, dalam bukunya Gizi dalam Kesehatan Reproduksi diketahui ibu menyusui dengan usia menyusui 0-6 bulan memerlukan tambahan energi 700 kkal dan 7-12 bulan $500 \mathrm{kkal}$, selain energi penambahan protein berdasarkan usia menyusui memerlukan tambahan sebesar $16 \mathrm{~g}$ dengan usia menyusui 0-6 bulan dan 12 g dengan usia menyusui 7-12 bulan ${ }^{6}$.

Status gizi pada ibu menyusui dapat ditentukan dengan pengukuran lndeks Massa Tubuh (IMT) yaitu berat badan (kilogram) per tinggi badan (meter) kuadrat ${ }^{5}$. Status gizi menurut Principle of Nutritional Assessment adalah keadaan tubuh yang merupakan hasil akhir dari keseimbangan antara zat gizi yang masuk ke dalam tubuh beserta fungsinya?

Berdasarkan Profil Kesehatan Kota Semarang 2015 diketahui bayi dengan pemberian ASI ekslusif hanya $87,21 \%$. Berdasarkan laporan puskesmas jumlah kematian bayi di Kota Semarang pada tahun 2016 meningkat dengan ditemukannya gizi buruk pada bayi. Terjadi 39 kasus di kota Semarang dan wilayah Kelurahan Bandaharjo merupakan salah satu penyumbang dengan $>2$ kasus terjadi di wilayah tersebut ${ }^{8}$. Berdasarkan permasalahan tersebut, maka peneliti merumuskan masalah apakah ada hubungan asupan makanan zat gizi makro dan status gizi ibu menyusui dengan kandung zat gizi makro pada ASI.

Tabel 1. Distribusi Karakteristik

\begin{tabular}{|c|c|c|c|c|}
\hline Variable & Minimum & Maksimum & Median & Mean \pm SD \\
\hline Usia Ibu (tahun) & 17 & 40 & 28 & $27.69 \pm 6.7$ \\
\hline Usia Menyusui (bulan) & 1 & 12 & 6 & $4.6 \pm 2.9$ \\
\hline Aktifitas Fisik & 1.45 & 1.55 & 1.45 & $1.45 \pm 0.25$ \\
\hline Berat Badan (kg) & 40.2 & 81.6 & 53,75 & $56.9 \pm 10.3$ \\
\hline Tinggi Badan (cm) & 137.5 & 165.5 & 151,25 & $151 \pm 5.3$ \\
\hline Pendapatan Keluarga & 1.500 .000 & 6.000 .000 & 2.000 .000 & $2214285.81 \pm 1240293$ \\
\hline Indeks Massa Tubuh $(\mathrm{kg} / \mathrm{m} 2)$ & 17.5 & 32.8 & 23.09 & $25.1 \pm 4.11$ \\
\hline Asupan Energi (kkal) & 1306.7 & 2727.3 & 2.217 .15 & $2248.7 \pm 275.3$ \\
\hline Tingkat Kecukupan Energi (\%) & $80 \%$ & $134 \%$ & $89 \%$ & $90.55 \% \pm 10 \%$ \\
\hline Asupan Karbohidrat (g) & 176.3 & 397.5 & 300.40 & $304.8 \pm 41.8$ \\
\hline Tingkat Kecukupan Karbohidrat (\%) & $46 \%$ & $98 \%$ & $78 \%$ & $78.06 \% \pm 10 \%$ \\
\hline Asupan Lemak (g) & 40.9 & 136.6 & 84.20 & $87.3 \pm 20.09$ \\
\hline Tingkat Kecukupan Lemak (\%) & $60 \%$ & $171 \%$ & $119 \%$ & $120.50 \% \pm 26 \%$ \\
\hline Asupan Protein (g) & 40.0 & 98.7 & 61.75 & $63.2 \pm 14.3$ \\
\hline Tingkat Kecukupan Protein (\%) & $62 \%$ & $144 \%$ & $95 \%$ & $97.14 \% \pm 21 \%$ \\
\hline Kandungan Energi ASI (kkal) & 35 & 96,5 & 63 & $61,3 \pm 12.8$ \\
\hline Kandungan Karbohidrat ASI (g) & 3.80 & 7.1 & 6.60 & $6.4 \pm 0.54$ \\
\hline Kandungan Lemak ASI (g) & 1.35 & 7,65 & 4.3 & $4.3 \pm 1.93$ \\
\hline Kandungan Protein ASI (g) & 0.55 & 2.7 & 1.10 & $1.35 \pm 1.7$ \\
\hline
\end{tabular}




\section{METODE}

Penelian ini merupakan observasi dengan desain Cross Sectional. Pemilihan subjek penelitian menggunakan teknik Purposive Sampling. Subjek dalam penelitian ini adalah ibu menyusui tinggal di Bandaharjo Semarang Jawa Tengah. Kriteria inklusi dalam penelitian ini adalah bersedia menjadi subjek penelitian dengan mengisi Informed Concent, tercatat sebagai warga Kelurahan Bandarharjo, menyusui dengan bayi usia 1-12 bulan, ASI dapat keluar sebanyak $100 \mathrm{ml}$. Sedangkan kriteria inklusi dalam penelitian ini adalah ibu mengalamai sakit kronis dan mengundurkan diri dalam penelitian. Berdasarkan hasil hitung jumlah sampel dengan rumus Slovin didapat sebanyak 42 subjek. Variabel bebas dalam penelitian ini ialah asupan gizi makro dan status gizi ibu, variable terikat ialah kandungan gizi makro pada ASI.

Data yang dikumpulkan adalah data identitas subjek, meliputi nama ibu dan ayah, usia ibu, usia menyusui, pengukuran tinggi badan menggunakan microtoice dengan tinggi maksimal $200 \mathrm{~cm}$, dan tingkat ketelitian $0,1 \mathrm{~cm}$, pengukuran berat badan menggunakan timbangan digital injak dengan ketelitian $0,1 \mathrm{~kg}$, pekerjaan ibu, pendapatan keluarga, pendidikan terakhir ibu, serta data biokimia meliputi ASI yang diambil sebanyak $100 \mathrm{ml}$ dalam kurun waktu 1x24jam. ASI disimpan di kantong ASI yang sudah diberikan pada ibu 2 hari sebelum dilakukan pengambilan data. Ibu diberikan informasi untuk menyimpan ASInya yang telah dipompa sendiri pada malam hari dan harus disimpan dalam lemari pendingin. ASI yang didapat dari subjek dibawa menggunakan Cooler Box lalu diberikan pada laboratorium patologi yang bertempat pada RSUP Kariadi untuk melihat hasil kandungan ASI berupa energi, karbohidrat, protein dan lemak yang ada pada ASI.

Pekerjaan ibu dikatagorikan menjadi $0=$ tidak bekerja $1=$ bekerja. Pendidikan pada ibu menyusui dibagi menjadi tidak sekolah dan SD, SMP dan SMA, Pendidikan diploma dan sarjana ${ }^{9}$, Pendapatan keluarga dikatagorikan menjadi pendapatan rendah $<1,5 \mathrm{Rp} / \mathrm{bl}$; sedang 1,5- 2,5juta Rp/bl; tinggi 2,53,5 jutat/bl; sangat tinggi $>3,5 \mathrm{juta} / \mathrm{bl}^{9}$. Aktifitas fisik ibu dikatagorikan menjadi ringan $(1,45)$, sedang $(1,55)$, dan berat $(1,75)$. Pengambilan data antropometri dilakukan dengan pengukuran Index Masa Tubuh (IMT) untuk melihat status gizi ibu. Data IMT dikatagorikan sebagai berikut ; kurus (jika $<18,5$ $\mathrm{kg} / \mathrm{m}^{2}$ ), normal (jika $18,5-<25 \mathrm{~kg} / \mathrm{m}^{2}$ ), gemuk (jika $\left.\geq 25 \mathrm{~kg} / \mathrm{m}^{2}\right)^{10}$.

Data asupan makanan ibu diperoleh melalui wawancara dengan menggunakan metode Food Recall dalam kurun waktu 24 jam. Penentuan jumlah asupan energi, karbohidrat, lemak, dan protein didapat dengan program bernama Nutrisurvey pada computer yang telah disesuaikan dengan makanan yang ada di Indonesia. Tingkat kecukupan asupan energi, karbohidrat, lemak, dan protein ibu ditentukan dengan cara membandingkan asupan ibu dengan kebutuhan, kebutuhan energi ibu ditentukan dengan rumus Harris Beneditct ${ }^{11}$. Jika diketahui nilai asupan perbandingan kebutuhan baik energi, karbohidrat, protein, dan lemak bernilai <90\% dinyatakan kurang, namun bila 90\%-110\% dinyatakan cukup dan bila lebih dari $>110 \%$ maka dinyatakan lebih ${ }^{12}$.

Tabel 2. Analisis Asupan Energi, Karbohidrat, Lemak, dan Protein berdasarkan status gizi pada ibu menyusui, pekerjaan, pendidikan terakhir dan aktifitas fisik

\begin{tabular}{|c|c|c|}
\hline Variabel & $\mathbf{n}$ & $\%$ \\
\hline \multicolumn{3}{|l|}{ Status gizi } \\
\hline Kurus & 4 & $9,5 \%$ \\
\hline Normal & 11 & $26,1 \%$ \\
\hline Gemuk & 27 & $64,4 \%$ \\
\hline \multicolumn{3}{|l|}{ Asupan Energi } \\
\hline Kurang & 21 & $50 \%$ \\
\hline Cukup & 19 & $45 \%$ \\
\hline Lebih & 2 & $5 \%$ \\
\hline \multicolumn{3}{|c|}{ Asupan Karbohidrat } \\
\hline Kurang & 38 & $90 \%$ \\
\hline Cukup & 4 & $10 \%$ \\
\hline \multicolumn{3}{|l|}{ Asupan Protein } \\
\hline Kurang & 19 & $45 \%$ \\
\hline Cukup & 11 & $26 \%$ \\
\hline Lebih & 12 & $29 \%$ \\
\hline \multicolumn{3}{|l|}{ Asupan Lemak } \\
\hline Kurang & 6 & $14 \%$ \\
\hline Cukup & 7 & $17 \%$ \\
\hline Lebih & 29 & $69 \%$ \\
\hline \multicolumn{3}{|c|}{ Kandungan Energi ASI } \\
\hline Rendah & 9 & $21 \%$ \\
\hline Normal & 27 & $60 \%$ \\
\hline Tinggi & 2 & $4 \%$ \\
\hline \multicolumn{3}{|c|}{ Kandungan Karbohidrat ASI } \\
\hline Rendah & 9 & $21 \%$ \\
\hline Normal & 31 & $74 \%$ \\
\hline Tinggi & 2 & $5 \%$ \\
\hline \multicolumn{3}{|c|}{ Kandungan Lemak ASI } \\
\hline Rendah & 3 & $7 \%$ \\
\hline Normal & 2 & $5 \%$ \\
\hline Tinggi & 37 & $88 \%$ \\
\hline \multicolumn{3}{|c|}{ Kandungan Protein ASI } \\
\hline Rendah & 20 & $48 \%$ \\
\hline Normal & 14 & $33 \%$ \\
\hline Tinggi & 8 & $19 \%$ \\
\hline \multicolumn{3}{|l|}{ Pekerjaan Ibu } \\
\hline Tidak Bekerja & 31 & $73 \%$ \\
\hline Bekerja & 11 & $26 \%$ \\
\hline \multicolumn{3}{|c|}{ Pendidikan Terakhir Ibu } \\
\hline Tidak Sekolah & 1 & $2 \%$ \\
\hline SD & 6 & $14 \%$ \\
\hline SMP & 12 & $28 \%$ \\
\hline SMA & 21 & $50 \%$ \\
\hline Perguruan Tinggi & 2 & $5 \%$ \\
\hline \multicolumn{3}{|l|}{ Aktifitas Fisik } \\
\hline Ringan & 22 & $55 \%$ \\
\hline Berat & 10 & $45 \%$ \\
\hline
\end{tabular}


Kandungan ASI dikatagorikan menjadi 3, kandungan energi ASI dinyatakan kurang jika $<65 \mathrm{~g} / \mathrm{dl}$; cukup jika $65-70 \mathrm{~g} / \mathrm{dl}$; lebih jika $>70 \mathrm{~g} / \mathrm{dl}$, kandungan karbohidrat ASI kurang jika $<6,78 \mathrm{~g} / \mathrm{dl}$; cukup jika 6,7-7,8g/dl; lebih jika >7,8g/dl, sedangkan untuk kandungan protein ASI kurang jika $<0,9 \mathrm{~g} / \mathrm{dl}$; cukup jika 0,9-1,2g/dl; lebih jika $>1,2 \mathrm{~g} / \mathrm{dl}$, dan kandungan lemak ASI kurang jika $<3,2 \mathrm{~g} / \mathrm{dl}$; cukup jika 3,2-3,6 g/dl ; lebih jika >3,6 g/d1 ${ }^{13}$. Uji normalitas yang dilakukan dengan uji Shapiro-Wilk dan analisis univariat digunakan untuk mendeskripsikan tiap-tiap variabel. Analisis bivariat yang dilakukan dengan uji korelasi Pearson.

\section{HASIL}

\section{Karakteristik Subjek Penelitian}

Tabel 1 menunjukkan karakteristik subjek dengan sampel 42 orang ibu menyusui dengan usia rata-rata 27 tahun. Diketahui pendapatan keluarga tergolong menengah kebawah dengan IMT katagori lebih. Tingkat kecukupan asupan energi subjek ratarata sebesar 90,55\%. Tingkat kecukupan asupan karbohidrat subjek rata-rata sebesar 78,06\%. Tingkat kecukupan asupan lemak subjek rata-rata sebesar $120,50 \%$. Tingkat kecukupan asupan protein subjek rata-rata sebesar 97,14\%. Kandungan enegi pada ASI tergolong cukup. Kandungan karbohidrat pada ASI subjek rata-rata subjek kurang $(<6,78 \mathrm{~g} / \mathrm{dl})$. Kandungan lemak pada ASI subjek rata-rata lebih $(>3,6 \mathrm{~g} / \mathrm{dl})$. Kandungan protein pada ASI subjek ratarata lebih $(>1,2 \mathrm{~g} / \mathrm{dl})$.

Katagori Status Gizi, Asupan Zat Gizi Makro, Kandungan Zat Gizi Makro ASI, Pekerjaan, Pendidikan Terakhir, Aktifitas Fisik
Pada tabel 2 menunjukan status gizi pada ibu sebagian besar memiliki katagori gemuk. Asupan energi, karbohidrat dan protein tergolong kurang sedangkan untuk asupan lemak ibu sebagian besar lebih hingga 69\%. Kandungan energi ASI normal sebanyak 27 orang $(60 \%)$. Kandungan karbohidrat ASI diketahui "cukup" sebanyak 31 orang (74\%) sedangkan nilai kandungan lemak ASI diketahui sebanyak 37 orang $(88 \%)$ dinyatakan "lebih" dan kandungan protein ASI diketahui sebanyak 20 orang (48\%) disimpulkan "kurang". Diketahui sebagian besar pendidikan terakhir ibu menyusui SMA dengan aktifitas fisik ibu 55\% dinyatakan ringan.

Uji Korelasi Index Masa Tubuh (IMT) dan Asupan Zat Gizi Makro Ibu dengan Kandungan Gizi Makro pada ASI

Tabel 3 menunjukan hasil uji korelasi Pearson antara IMT dengan kandungan zat gizi makro pada ASI dan asupan zat gizi makro ibu dengan kandungan zat gizi makro pada ASI. IMT tidak berhubungan dengan kandungan energi, karbohidrat, lemak dan protein pada ASI. Perhitungan asupan energi berhubungan dengan energi pada ASI $(r=0,876 ; p=0,021)$, asupan karbohidrat berhubungan dengan kandungan karbohidrat ASI $(r=0,925 ; p=0,000)$, asupan protein berhubungan dengan protein ASI $(r=0,774 ; p=0,000)$, dan asupan lemak berhubungan dengan kandungan lemak ASI $(r=0,785 ; p=0,000)$. Nilai $r$ yang positif menunjukan bahwa semakin tinggi asupan energi, karbohidrat, lemak, dan protein subjek maka semakin tinggi kandungan energi, karbohidrat, lemak dan protein pada ASI.

Tabel 3. Hasil Uji Korelasi Atara Index Masa Tubuh dan Asupan Zat Gizi Makro Ibu Dengan Kandungan ASI

\begin{tabular}{lcccccccc}
\hline Variabel & \multicolumn{2}{l}{$\begin{array}{l}\text { Kandungan } \\
\text { Enegi ASI }\end{array}$} & \multicolumn{2}{l}{$\begin{array}{l}\text { Kandungan } \\
\text { Karbohidrat ASI }\end{array}$} & \multicolumn{2}{c}{$\begin{array}{l}\text { Kandungan } \\
\text { Lemak ASI }\end{array}$} & \multicolumn{2}{c}{$\begin{array}{l}\text { Kandungan } \\
\text { Protein ASI }\end{array}$} \\
\hline & $r$ & $P$ & $R$ & $P$ & $R$ & $p$ & $r$ & $p$ \\
\hline IMT & 0.711 & 0.540 & 0,018 & 0,742 & 0,472 & 0,333 & 0,669 & 0,296 \\
Asupan Energi & 0.876 & 0.021 & 0,825 & 0,040 & 0,733 & 0,043 & 0,625 & 0,031 \\
Asupan Karbohidrat & 0,670 & 0,110 & $0,925 * *$ & 0,000 & 0.108 & 0.496 & 0.309 & 0.046 \\
Asupan Lemak & 0,567 & 0,443 & 0.054 & 0.735 & $0.774 * *$ & .000 & 0.156 & 0.323 \\
Asupan Protein & 0,271 & 0,356 & 0.130 & 0.413 & 0.087 & 0.582 & $0.785^{* *}$ & 0.000 \\
\hline
\end{tabular}

\section{PEMBAHASAN}

Terjadi penambahan kebutuhan asupan makanan pada ibu berupa energi sebesar 700 kkal/hari dengan 16g/hari protein pada 6 bulan pertama dan $500 \mathrm{kkal} /$ hari dengan $12 \mathrm{~g} /$ hari pada 6 bulan kedua. Kebutuhan gizi ibu menyusui dapat dipenuhi dengan meningkatan serta menjaga kecukupan asupan ${ }^{5}$. Kebutuhan asupan makanan ibu ikut bertambah berdasarkan anjuran kebutuhan asupan makanan yang dilihat dari usia ibu dengan usia menyusui ${ }^{3,5}$.
Sebagian besar responden mempunyai asupan energi, karbohidrat dan protein yang kurang dari kebutuhan, sementara itu sebagian besar responden memiliki asupan lebih pada lemak. Kondisi ini dapat dikaitkan dengan tingkat pendapatan keluarga dan pendidikan ${ }^{14}$. Pendapatan keluarga di Kelurahan Bandarharjo tergolong menengah kebawah yakni Rp. 1.500.000-Rp. $2.500 .000 /$ bulan. Sebagian besar responden ibu tidak bekerja dan pendidikan terakhir rata rata SMA. Sehingga menyebakan daya beli rendah menjadikan 
terbatasnya akses dan pemilihan bahan makanan untuk dikonsumsi ${ }^{15}$. Asupan makanan tinggi lemak pada ibu dikarenakan sebagian besar asupan berjenis gorengan berupa tempe, mendoan dan bakwan. Asupan rendah karbohidrat dan protein dikarenakan porsi makanan ibu yang teralu sedikit.

Harga makanan jenis gorengan relatif lebih murah dibandingkan dengan harga makanan sumber protein kususnya protein hewani ${ }^{16}$. Diketahui asupan makanan ibu sekali makan dalam satu piring bersamaan dengan makanan yang diberikan pada anaknya berisikan menu berupa nasi rata-rata sebanyak satu centong, sayur, gorengan serta sedikit lauk berupa ikan atau telur yang dirasa sudah cukup. Hal ini dapat diasumsikan asupan makanan pada ibu menyusui dipengaruhi oleh kebiasaan makan, pedapatan keluarga dan pendidikan yang dapat mempengaruhi status gizi.

IMT pada ibu menyusui menunjukan $64 \%$ jauh dari katagori IMT normal. Keadaan gizi pada ibu terjadi karena tidak tercapainya gizi seimbang ${ }^{17}$. Penderita gizi kurang merupakan akibat dari asupan makanan yang tidak tercukupi, sedangkan penderita gizi lebih diakibatkan asupan makanan yang berlebihan. Untuk mencegah risiko IMT rendah atau lebih pada ibu, maka selama kehamilan ibu sudah harus dalam kondisi status gizi yang baik ${ }^{18}$.

Tingginya status gizi ibu berdasarkan IMT dikarenakan terdapatnya peningkatan berat badan ibu ketika masa kehamilan, namun ibu dengan IMT gemuk dalam penelitian ini tidak dapat di simpulkan karena asupan makanan berlebih dan perlu penurunan berat badan. Perhitungan persentase lemak diperlukan untuk mengetahui perbandingan masa lemak dan non lemak (fat free mass) pada tubuh seseorang, persentase lemak tubuh dapat diperoleh dari pengukuran dengan menggunakan Bioelectrical Impedance Analysis (BIA) ${ }^{19}$. Persentase lemak tubuh ibu dapat berkurang sejalan dengan pemberian ASI, hal ini dinyatakan pada penelitian hubungan pemberian ASI ekslusif dengan penurunan persentase lemak tubuh ibu menyusui dengan $p=0,007^{20,21}$.

Kandungan karbohidrat ASI berupa laktosa sebagai karbohidrat utama pada ibu menyusui Kelurahan Bandarharjo menunjukan tergolong kurang. Kurangnyanya laktosa yang dihasilkan oleh ASI dapat timbulnya resiko bayi mengalami diare ${ }^{22}$. Tidak hanya disebabkan kurangnya kandungan laktosa pada ASI, jika kandungan protein dan lemak pada ASI kurang akan mengakibatkan masalah pertumbuhan pada bayi yaitu: stunting, wasting, serta beresiko terjadinya keterbelakangan mental serta cacat $^{23,24}$.

Uji korelasi yang dilakukan antara status gizi dengan kandungan zat gizi makro pada ASI dalam penelitian ini tidak ada hubungan, diketahui nilai $p$
$>0,05$. Berbeda dengan penelitian pada tahun 2009, penelitian dengan judul hubungan antara kandungan lemak ASI dengan status gizi ibu dan anak di Iran menunjukan adanya hubungan dengan nilai $p=0,001^{25}$. Hubungan asupan dan status gizi ibu pada review jurnal bersangkutan menyatakan perlunya peningkatan asupan makanan pada ibu menyusui agar kandungan ASI yang dihasilkan dapat berkualitas sehingga memenuhi kebutuhan bayinya ${ }^{26}$. Penelitian lain untuk yang melihat produksi ASI yang dilakukan pada ibu menyusui di posyandu Desa Karang Kedawang Kecamatan Sooko Kabupaten Mojokerto untuk melihat korelasi antara nilai IMT dengan ASI $p=0,129$ dan LILA $p=0,319$ yang artinya tidak adanya korelasi antara kandungan ASI dengan status gizi ${ }^{27}$.

Uji hubungan asupan makanan energi, karbohidrat, protein, dan lemak dengan kandungan zat gizi makro pada ASI keseluruhan terdapat hubungan signifikan dikarenakan nilai $p<0,05$. Hasil penelitian ini berbeda dengan penelitian yang dilakukan oleh adesty pada tahun 2016 yang menunjukan tidak ada hubungan antara asupan ibu dengan kandungan lemak pada $\mathrm{ASI}^{28}$. Perbedaan penelitian tersebut dikarenakan asupan makanan pada ibu menyusui tergolong sebagian besar berlebih dan pengambilan sampel ASI dengan metode yang berbeda. Penelitian dilakuakan Francois menunjukan adanya hubungan antara asupan asam lemak pada, minyak kelapa, minyak ikan, minyak goreng canola, mentega dari coklat yang dikonsumsi ibu menyusui dapat meningkatkan kandungan asam lemak pada $\mathrm{ASI}^{29}$. Sebagian besar responden pada penelitian ini memiliki usia menyusui 4 bulan, menurut literatur tahun 2013 selain asupan dan status gizi yang dapat mempengaruhi karakteristik serta kandungan zat gizi makro pada ASI, ASI juga dapat dipengaruhi oleh paritas, kembalinya masa menstruasi, dan frekuensi menyusui namun pada penelitian ini tidak memiliki data tersebut yang memungkinkan dapat mempengaruhi hasil penelitian ${ }^{13}$.

\section{SIMPULAN}

Status gizi ibu menyusui tidak berhubungan dengan zat gizi makro pada ASI sedangkan asupan zat gizi makro pada ibu menyusui berhubungan dengan kandungan zat gizi makro pada ASI.

\section{SARAN}

Perlu diberikan edukasi pada ibu menyusui tentang pentingnya mengetahui kebutuhan asupan makanan yang sesuai kebutuhan agar tecukupi dan terhindar terjadi asupan makanan yang kurang atau lebih. 


\section{DAFTAR PUSTAKA}

1. Koo Winston, Tank Surinder, Martin Sandra and Shi Runhua. Human Milk and Neurodevelopment in Children with Very Low Birth Weight: a Systematic Review. Nutrition Journal. 2014; 13:94

2. Ahrabi, Ali Faraghi, and Richard J. Schanler. "Human milk is the only milk for premies in the NICU." Early human development 89; 2013: S51-S53.

3. Haileslassie Kiday, Mulugeta and Meron Girma. Feeding practices, Nutritional status and associated factors of lactating women in Samre Woreda, South Eastern Zone of Tigray, Ethiopia. Nutritional Journal. 2013; 12:28.

4. McManaman J.L. Margaret C. Neville. Mammary physiology and milk secretion. Advanced Drug Delivery Reviews 55. 2003. 629-641.

5. Gibson, RS. Principles of Nutritional Assessment. Oxford University Press. New York. 1990. Di dalam: Gumala. Tingkat Konsumsi Zat Gizi Berdasarkan Karakterisik Pasien di BPK RS Jiwa. Provinsi Bali. 2011.

6. Wambach Karen, Williams E Domian, Goertz Sallie, Wurtz Heather, BSN,3 and Kelli Hoffman. "Exclusive breastfeeding experiences among Mexican American women." Journal of Human Lactation; 2016: 103-111.

7. Haschke, Ferdinand, and Martin A. van't Hof. "Euro-Growth references for breast-fed boys and girls: influence of breast-feeding and solids on growth until 36 months of age." Journal of pediatric gastroenterology and nutrition; 2000: S60-S71.

8. Profil Kesehatan Kota Semarang. Semarang: Dinas Kesehatan Kota Semarang. 2015.

9. Nurmanaf, Supadi dan Achmad Rozany. "Pendapatan dan Pengeluaran Rumah Tangga Pedesaan dan Kaitannya Dengan Tingkat Kemiskinan [Tesis]. Bali: Universitas Udayana (2012).

10. WHO Appropriate body-mass index for Asian populations and its implications for policy and intervention strategies. Department of Nutrition for Health and Development. 2004. Vol 363. : $157-63$

11. Rodica, Alina, Liliana, and Laura. Basal Metabolic Rate In Metabolic Disorders. Proc. Rom. Acad., Series B, 2015, 17(2), p. 137-143

12. Angela P F. Hubungan Antar Asupan Energi, Karbohidrat, Protein, dan Lemak Terhadap Obesitas Sentral Pada Orang Dewasa Di Desa Kepuharjo, Kecamatan Cangkringan [Skripsi]: Yogyakarta. Universitas Sanata Darma: 2016
13. Ballard Olivia, Ardythe L. Morrow,PhD, Msc "Human Milk Compositions: Nutrient and Bioactive Factors". Pediatr Clin North Am. 2013; 60(1): 49-74.

14. Angela P F. Hubungan Antar Asupan Energi, Karbohidrat, Protein, dan Lemak Terhadap Obesitas Sentral Pada Orang Dewasa Di Desa Kepuharjo, Kecamatan Cangkringan [Skripsi]: Yogyakarta. Universitas Sanata Darma: 2016

15. Indrawati, A. 2012. Hubungan Status Pekerjaan Ibu dengan Pemberian Air Susu Ibu (ASI) Eksklusif pada Bayi Saat Usia 0-6 Bulan di Bidan Praktik Mandiri Kota Semarang. Available at: jurnal.abdihusada.com. Accessed on Februari 3, 2017.

16. Kementrian Perdagangan Repoblik Indonesia. Sistempemantauan Pasar Kebutuhan Pokok (SP2KP). Informasi Pasar [home page on internet]. [update 2017 Des 12]. Avaible from https://ews.kemendag.go.id/

17. Widajanti, L. Survey Konsumsi Gizi. Balai Pustaka Universitas Diponegoro: Semarang. 2009.

18. Almatsier,S. Penuntun Diet, Penerbit PT Gramedia Pustaka Utama, 2004. Jakarta.

19. Evita Februiyan Kusuma Ningrum, Indri Mulyasari, S.Gz., M.Gizi, Dian Oktianti S. Farm, M.Sc, Apt, Hubungan Tingkat Kecukupan Energi Dan Protein Dengan Produksi Asi Pada Ibu Menyusui Di Desa Bawen Kecamatan Bawen [Tesis]. Kabupaten Semarang: STIKES Ngudi Waluyo: 2016.

20. Br Manik, Rosmaria .Korelasi Persentase Lemak Tubuh Ibu Menyusui Bayi Aterm dengan Kadar Lemak dan Protein ASI. Masters [Thesis], Universitas Andalas. 2016.

21. Yulia Harsanti, Aryu Candra Kusumastuti. Hubungan Pemberian ASI ekslusif dengan Penurunan Persentase Lemak Tubuh Ibu Menyusui. Journal of Nutrition College, 2 (4), 2013.

22. Arisman. Gizi dalam Daur Kehidupan, Penerbit Buku kedokteran EGC. 2003. Jakarta.

23. Gott Fredson, and Lauren. Maternal Stress, Breastmilk IGF-1, and Offspring Growth among Breastfeeding Mothers-Infant Pairs in the Tampa Bay Area. University of South Florida, 2015.

24. Peter Fürst. "Dioxins, polychlorinated biphenyls and other organohalogen compounds in human milk. Levels, correlations, trends and exposure through breastfeeding." Molecular nutrition \& food research. 2006: 922-933.

25. Nikniaz, L., et al. "Association Between Fat Content of Breast Milk and Maternal Nutritional Status and Infants' weight in tabriz, iran". 
Malaysian journal of nutrition. 2009: 15(1) 3744.

26. Chapman, Donna J., and Laurie NommsenRivers. "Impact of maternal nutritional status on human milk quality and infant outcomes: an update on key nutrients." Advances in Nutrition: An International Review Journal 3.3 (2012): 351-352.

27. Pujiastuti, Nurul. "Korelasi Antara Status Gizi Ibu Menyusui Dengan Kecukupan ASI Di Posyandu Desa Karang Kedawang Kecamatan
Sooko Kabupaten Mojokerto." Jurnal Keperawatan 2010: 1(2); 126-137.

28. Ardesy Melizah Kurniati, Diana Sunardi, Ali Sungkar, Saptawati Bardosono, Neng Tine Kartinah. "Associations of maternal body composition and nutritional intake with fat content of Indonesian mothers' breast milk". Paediatrica Indonesiana. 2016;56 (5): 298-304.

29. F.A Cindy, C. L Connor, Wander C Rosemary, "Acute effects of dietary fatty acids on the fatty acids of human milk". Am J Clini Nurt 1998: 63301. 